\title{
Armed Opposition Groups and the Right to Exercise Control over Public Natural Resources: A Legal Analysis of the Cases of Libya and Syria
}

\author{
Daniëlla Dam-de Jong ${ }^{1}$
}

Published online: 25 March 2015

(C) The Author(s) 2015. This article is published with open access at Springerlink.com

\begin{abstract}
This article examines whether international law provides a legal basis for the exploitation of natural resources by armed opposition groups. This issue is particularly pertinent in light of the ongoing armed conflict in Syria-and the 2011 armed conflict in Libya, where third states are looking for ways to provide nonmilitary support to the opposition movement, including by allowing it to export oil. This article examines three potential legal bases for a right for armed opposition groups to exploit natural resources: international humanitarian law, the recognition of the armed opposition group as the representative of the state and its recognition as the representative of the people. While this article concludes that current international law does not allow armed opposition groups to exploit natural resources, it argues in favour of applying the concept of usufruct from international occupation law to internal armed conflicts. On the basis of this concept, highly organised armed opposition groups would be granted a right to exploit the natural resources situated within the territory under their control for the purpose of establishing and maintaining a civilian administration.
\end{abstract}

Keywords Internal armed conflicts - Exploitation of natural resources · Armed opposition groups · Governments · Recognition - Self-determination · Usufruct

This article is based on her book entitled International Law and Governance of Natural Resources in Conflict and Post-Conflict Situations (Cambridge University Press, Cambridge 2015).

Daniëlla Dam-de Jong

d.a.dam@law.leidenuniv.nl

1 Assistant Professor at the Grotius Centre for International Legal Studies of Leiden University,

Leiden, The Netherlands 


\section{Introduction}

In 2011, revolutionary forces in Libya, labelling themselves the National Transitional Council (NTC), took up arms against the government which had been led by Colonel Muammar Gadhafi for more than 42 years. Following Colonel Gadhafi's excessive response to the insurrection, most notably the ordering of systematic and widespread attacks against the civilian population, the international community stepped in. In addition to authorizing military action, ultimately leading to the fall of the Gadhafi regime, the UN Security Council also imposed sanctions against the Libyan authorities. These included a freezing of the assets of the Libyan National Oil Corporation as a 'potential source of funding for [Gadhafi's] regime'. ${ }^{1}$ Moreover, the Council explicitly expressed and affirmed its determination to ensure that the frozen assets 'shall, at a later stage, as soon as possible be made available to and for the benefit of the people of the Libyan Arab Jamahiriya'. ${ }^{2}$ Indeed, after the armed conflict had ended and a transitional government had been installed, the Security Council removed the petroleum sanctions. ${ }^{3}$

The current situation in Syria resembles, to a certain extent, the situation in Libya before the fall of the Gadhafi regime. Also in Syria, protests broke out in 2011 against the government led by Bashar Al-Assad, which were severely repressed by the Assad government, resulting in an armed conflict which is still ongoing. In this situation, however, the Security Council was unable to adopt measures to stop the atrocities due to differences of opinion among its permanent members. This prompted the US and the EU in 2011 to impose sanctions against the Syrian authorities, including petroleum sanctions. Most interesting in this respect are the sanctions imposed by the EU, which provide an explicit exemption for oil exports from rebel-held territory in order to 'support and help the opposition'. 4 The EU decided that competent authorities in EU member states should consult with the Syrian National Coalition for Opposition and Revolutionary Forces (SNC) before approving a particular transaction. This decision is striking, since it formulates a presumption that the opposition movement is entitled to dispose of Syrian oil reserves.

As a general starting point, it should be noted that international law does not formulate a clear-cut right for armed opposition groups to exploit natural resources (Sect. 2). It accords the right to dispose freely of natural resources to states and peoples (Sect. 3). The question that this article therefore aims to answer is whether armed opposition groups can claim a right to dispose of natural resources situated within national jurisdiction based on the premise that they represent either the state or its people. It is important to note here that the Libyan and Syrian armed conflicts are not the first in which armed opposition groups turn to natural resources to finance their

\footnotetext{
1 See UN Security Council Res. 1970 and 1973 (2011), notably para. 17 of Res. 1970, para. 19 and Annex II of Res. 1973.

2 See ibid., para. 18 of Res. 1970 and para. 20 of Res. 1973.

3 See UN Security Council Res. 2009 (2011), para. 14.

${ }^{4}$ Council of the European Union, Press release: Council eases sanctions against Syria to support opposition and civilians, EU Doc. 8611/13, 22 April 2013. For the decision, see Council Regulation (EU) No. 697/2013 of 22 July 2013 amending Regulation (EU) No. 36/2012 concerning restrictive measures in view of the situation in Syria, OJ 2013, L 198/28, under Art. 6a.
} 
armed struggle. In recent decades, natural resources have become one of the primary means for these groups to finance their activities. Examples include the União Nacional para a Independência Total de Angola (UNITA) in Angola, the Revolutionary United Front (RUF) in Sierra Leone and the Forces Nouvelles in Côte d'Ivoire, which all turned to diamonds as a source of conflict revenues. The role that natural resources play in internal armed conflicts has also been the object of extensive studies in social sciences literature regarding the political economy of armed conflict. ${ }^{5}$

The armed conflicts in Libya and Syria however share two characteristics which make them especially relevant as case studies. In these armed conflicts the legitimacy of the respective governments was/is severely contested by a significant part of the world community as a consequence of the atrocities committed by these governments against their population. In addition, the major armed opposition groups in Libya and Syria-the NTC for Libya and the SNC for Syria-enjoy(ed) the sympathy of a significant part of the world community, which is illustrated by the widespread recognition of these groups by foreign states. The question is therefore to what extent these facts impact upon the legal status of the opposition movements and whether this would entitle them to exercise control over public natural resources (Sects. 4 and 5). Finally, this article explores the possibilities for granting armed opposition groups a right to exploit natural resources based on a factual determination of effective control over territory and their ability to respect international humanitarian law (Sect. 6).

\section{The International Legal Framework for the Exploitation of Natural Resources by Armed Opposition Groups}

Situations of armed conflict are primarily regulated by international humanitarian law, which is generally considered the lex specialis for these situations. ${ }^{6}$ Moreover, international humanitarian law is the only field of international law which directly accords rights to armed groups. ${ }^{7}$ It is for these reasons that any right for armed groups to exploit natural resources would primarily have to be based on this field of international law.

As a starting point it can be noted that international humanitarian law does not contain specific rules regulating the exploitation of natural resources. The reason for this is evident: international humanitarian law is designed to regulate the waging of an armed conflict and not to address conflict-sustaining activities, such as the exploitation of natural resources. The most relevant rules that apply to

\footnotetext{
5 See e.g. Ballentine and Sherman (2003).

6 This view has been consistently held by the International Court of Justice in its case law. See International Court of Justice, Legality of the Threat or Use of Nuclear Weapons, Advisory Opinion of 8 July 1996, ICJ Reports 1996, para. 25; International Court of Justice, Legal Consequences of the Construction of a Wall in the Occupied Palestinian Territory, Advisory Opinion of 9 July 2004, ICJ Reports 2004, p. 136, paras. 111-112; and International Court of Justice, Case concerning Armed Activities on the Territory of the Congo (Democratic Republic of the Congov.Uganda), Judgment of 19 December 2005, ICJ Reports 2005, p. 168, para. 216.

7 The 1977 Additional Protocol II to the 1949 Geneva Conventions accords several rights to armed groups, amongst which are a right to humane treatment for members of armed groups who have been deprived of their liberty (Art. 5) and medical care for the wounded (Art. 7).
} 
natural resources exploitation in internal armed conflicts relate to the protection of property and civilian objects. Furthermore, they are all formulated in terms of prohibitions. The relevant rules include the prohibition against pillage (Art. $4(2)(\mathrm{g})$ of Additional Protocol II), the prohibition against destroying or seizing the property of a hostile party (Art. 8(2)(e)(xii) of the ICC Statute as derived from Art. 23(g) of the 1907 Hague Regulations) and the prohibition against attacking, destroying, removing or rendering useless objects indispensable to the civilian population (Art. 14(2) of Additional Protocol II). ${ }^{8}$ Without entering into the particularities of these provisions, it should be noted that they do not contain exceptions that would allow armed opposition groups to systematically exploit natural resources for the purpose of financing an armed conflict or otherwise. ${ }^{9}$ In addition, the prohibitions contained in these provisions apply to internal armed conflicts generally. ${ }^{10}$

A right for armed opposition groups to exploit natural resources cannot therefore be based on existing international humanitarian law. The following sections focus on the general legal framework for the exploitation of natural resources and specifically analyse whether armed groups could claim a right to exploit natural resources based on the premise that they represent the holders of the right to dispose freely of natural resources. Section 3 identifies these right holders, while Sects. 4 and 5 focus on the issue of representation.

\footnotetext{
8 The relevant provisions read as follows. Art. 4(2)(g) of Additional Protocol II to the Geneva Conventions, adopted on 8 June 1977 (1125 UNTS 609), determines that pillage against persons who do not take a direct part or who have ceased to take part in hostilities remains prohibited at any time and in any place whatsoever. Art. 23(g) of the 1907 Hague Regulations determines that parties to an armed conflict may not destroy or seize enemy property unless imperatively demanded by the necessities of war. Finally, Art. 14(2) of Additional Protocol II stipulates that '[s]tarvation of civilians as a method of combat is prohibited. It is therefore prohibited to attack, destroy, remove or render useless, for that purpose, objects indispensable to the survival of the civilian population, such as foodstuffs, agricultural areas for the production of foodstuffs, crops, livestock, drinking water installations and supplies and irrigation works'.

9 For a thorough analysis of these and other provisions in relation to natural resources exploitation in internal armed conflicts, see Dam-de Jong (2015), pp. 215-245. For a discussion of pillage as a war crime under international criminal law in relation to natural resources exploitation, see Van den Herik and Damde Jong (2011), pp. 237-273.

10 The prohibition of pillage is considered to constitute customary international law applicable to noninternational armed conflict, as confirmed by the Appeals Chamber of the ICTY and the Special Court for Sierra Leone. See Hadzihasanovic, Alagic and Kubura (IT-01-47), ICTY, 11 March 2005, Decision on Joint Defence Interlocutory Appeal of Trial Chamber Decision on Rule 98bis Motions for Acquittal, para. 37; and The Prosecutor v. Moinina Fofana and Allieu Kondewa, Special Court for Sierra Leone, 28 May 2008, Appeals Chamber Judgment, para. 390. The prohibition against destroying or seizing the property of a hostile party is codified in the 1907 Hague Regulations, which apply exclusively to international armed conflicts. Its applicability to internal armed conflicts may nonetheless be derived from Art. $8(2)$ (e)(xii) of the ICC Statute, which criminalises the destruction and seizure of the property of an adversary. Finally, the prohibition against attacking, destroying, removing or rendering useless objects indispensable to the civilian population, codified in Art. 14(2) of Additional Protocol II applicable to internal armed conflicts which satisfy a number of conditions, can be regarded as a specification of the general obligation of humane treatment set out in Art. 3 of the 1949 Geneva Conventions, which applies to internal armed conflicts generally.
} 


\section{Subjects of the Right to Dispose Freely of the State's Natural Resources}

International law establishes a right for states and peoples to freely exploit their natural resources. ${ }^{11}$ This right originates in UN General Assembly Resolution 523 (IV) of 12 January 1952, which formulates a right for 'under-developed countries' to freely determine the use of their natural resources. Soon after the adoption of this resolution, the right developed along two different but interrelated tracks. First, the right was asserted in terms of the principle of permanent sovereignty over natural resources (PSNR), authoritatively laid down in the 1962 Declaration on Permanent Sovereignty over Natural Resources. ${ }^{12}$ This declaration proclaims a right for peoples and nations to permanent sovereignty over their natural wealth and resources, while conditioning the exercise of this right on the premise that this must be done 'in the interest of their national development and of the wellbeing of the people of the state concerned'. ${ }^{13}$ In addition, as Chile proposed, the right of peoples to freely dispose of their natural resources was inserted into the two human rights covenants of 1966 as inherent in their right to selfdetermination. $^{14}$

The principle of PSNR thus emerged notably within UN General Assembly Resolutions adopted during the 1950s and 1960s, in the era of decolonization. It was advanced by newly independent and developing countries as a means of protecting their ownership rights over the natural wealth and resources situated within their territory. ${ }^{15}$ At the time, the main idea behind the principle was to provide these countries with the legal tools to regain control over their natural resources and to exploit them for their own benefit. It is also in this context that the Chilean proposal to insert a right for peoples to freely dispose of their natural resources in the 1966 human rights covenants must be regarded. At first, the main purpose of the principle of PSNR and the right to self-determination was therefore to protect 'weaker' states against 'stronger' states. This explains the strong emphasis of early PSNR-related resolutions on the right of states to regulate foreign investment and the more controversial right to nationalise natural resources. At the time, the principle was therefore primarily asserted as an attribute of state sovereignty.

\footnotetext{
11 See also on this topic Dam-de Jong (2015), pp. 34-50.

12 See UN General Assembly Res. 1803 (XVII) on Permanent Sovereignty over Natural Resources, 14 December 1962.

13 Declaration on Permanent Sovereignty over Natural Resources, UN General Assembly Res. 1803 (XVII) of 14 December 1962.

14 The original proposal for Art. 1(2) introduced by Chile in 1952 provided in relevant part that 'the right of the peoples to self-determination shall also include permanent sovereignty over their natural wealth and resources'. For a discussion of the Chilean proposal, see Schrijver (1997), pp. 49-56.

15 For a detailed examination of the principle of permanent sovereignty over natural resources, see Schrijver (1997), Rosenberg (1983) and Elian (1979).
} 
Since then, the principle of PSNR has been inserted in several treaties, especially in the field of international environmental law. ${ }^{16}$ In addition, it has found recognition in the relevant practice of the UN Security Council ${ }^{17}$ and has been recognized by the International Court of Justice as having customary international law status. ${ }^{18}$ It can therefore be concluded that the principle of permanent sovereignty has a firm status in international law. Furthermore, whereas in its early years the emphasis of the principle was on (re)affirming the right of newly independent and developing countries to dispose of their natural resources without external interference, the emphasis of the principle shifted towards a rights and duty-related concept with internal dimensions. ${ }^{19}$ As will be explained in Sect. 5, this has also led to a revaluation of peoples as subjects and beneficiaries of the principle. Before entering into this discussion, which is linked to the question of whether a right for armed groups to dispose of natural resources within national jurisdiction can be based on an assumption that they represent the people of the state, the following section will focus on the principle of PSNR as an attribute of state sovereignty and examines the question of whether and, if so, under which conditions, an armed opposition group may exploit natural resources on behalf of the state.

\section{State Representation and the Right to Exploit Public Natural Resources Situated Within National Jurisdiction}

The principle of PSNR attributes a right to dispose freely of natural resources to states and therefore assumes the existence of institutions to represent the state. ${ }^{20}$ The existence of such representative institutions is even considered to constitute an essential aspect of statehood, as is apparent from the definition of a state as codified in the 1933 Montevideo Convention on the Rights and Duties of States. This

\footnotetext{
16 Examples include the preamble to the Convention on the Prevention of Marine Pollution by Dumping of Wastes and Other Matter, 29 December 1972, 1046 UNTS 120; Art. 193 of the United Nations Convention on the Law of the Sea, 10 December 1982, 1833 UNTS 3; Art. 3 of the Convention on Biological Diversity, 5 May 1992, 1760 UNTS 79; para. 8 of the preamble to the UN Framework Convention on Climate Change, 9 May 1992, 1771 UNTS 107; para. 15 of the preamble to the United Nations Convention to Combat Desertification in Countries Experiencing Serious Drought and/or Desertification, Particularly in Africa, 17 June 1994, 1954 UNTS 3; Art. 7 of the UN Convention on the Law of the Non-Navigational Uses of International Watercourses, 21 May 1997, 36 ILM 700 (1997).

17 See e.g. Presidential Statement on 'Maintenance of international peace and security: natural resources and conflict', UN Doc. S/PRST/2007/22 of 25 June 2007, para. 2, in which the Security Council reaffirmed that 'every state has the full and inherent sovereign right to control and exploit its own natural resources in accordance with the Charter and the principles of international law'; and UN Security Council Res. 1457 (2003) on 'The situation concerning the Democratic Republic of the Congo', adopted on 24 January 2003, para. 2 of the preamble, in which the Security Council reaffirmed 'the sovereignty of the Democratic Republic of the Congo over its natural resources'.

18 See e.g. International Court of Justice, Armed Activities on the Territory of the Congo (Democratic Republic of the Congo v. Uganda), Judgment of 19 December 2005, ICJ Reports 2005, para. 244.

19 See Schrijver (1997); and Dam-de Jong (2015).

${ }^{20}$ See on the issue of state representation in relation to natural resources also Dam-de Jong (2015), pp. 50-57.
} 
Convention determines that a state should possess a government in addition to a defined territory and a permanent population. ${ }^{21}$ It is therefore the government which is entitled to exercise control over the state's natural resources to the exclusion of other entities. Section 4.1 examines the criteria that international law formulates for the recognition of an entity as the representative of the state in international law, while Sect. 4.2 takes a closer look at the attitude of the international community with respect to the Libyan and Syrian authorities after the outbreak of the protests in these states. The aim of this section is to show that once an entity has become the government of a state, there is a presumption that it remains the representative of the state in international law until it has effectively been removed. This observation is important for the purpose of determining the conditions under which armed opposition groups may qualify as the new government, discussed in Sect. 4.3.

\subsection{Legal Criteria for State Representation}

International law comprises two criteria which need to be satisfied for an entity to qualify as the government: an entity should be able to exercise authority over state territory and the population and it should possess a valid legal title to this effect. ${ }^{22}$ In most cases these criteria do not pose any particular problems for the purpose of establishing which entity qualifies as a government and is therefore entitled to exercise the right to exploit the state's natural resources and to issue concessions on its behalf. However, there are some instances where the situation leaves room for doubt. This is particularly so when a government no longer exercises effective authority over the whole territory of the state as a consequence of the outbreak of internal armed conflict or when a government has assumed power through unconstitutional means.

The requirement that a government exercises authority over territory and the population is referred to as the doctrine of effectiveness of governmental power. Effective control over territory and the population is considered to be the single most important criterion for determining which entity is considered to represent the state in international law. ${ }^{23}$ The question arises whether international law would allow an armed opposition group to establish itself as the new government while the conflict is still ongoing, based on this group exercising effective control over portions of the state territory. It is important to note in this respect that international law contains rules prohibiting the premature recognition of an opposition movement as the new government, precisely to prevent situations in which third states all too easily switch sides according to their convenience. International law presumes that the established authorities continue to represent the state as a whole as long as the armed conflict is in progress. ${ }^{24}$ As noted by Sir Hersch Lauterpacht:

\footnotetext{
21 Art. 1 of the Montevideo Convention on the Rights and Duties of States, 26 December 1933, 165 LNTS 19.

22 See Crawford (2007), p. 56, stating that government as a criterion for statehood implies both 'the actual exercise of authority, and the right or title to exercise that authority'.

23 See e.g. Talmon (1998); Lauterpacht (2013) (first published 1947), pp. 98-114.

24 See Lauterpacht (2013) (first published 1947), p. 93.
} 
So long as the lawful government offers resistance which is not ostensibly hopeless or purely nominal, the de jure recognition of the revolutionary party as a government constitutes premature recognition which the lawful government is entitled to regard as an act of intervention contrary to international law. ${ }^{25}$

This is still the prevailing view in legal doctrine today. ${ }^{26}$ In other words, as long as the outcomes of an armed conflict are undecided, any act recognising the opposition movement as the de jure government is unlawful and entails the responsibility of the recognizing state.

This also implies that it is the de jure government that is exclusively entitled to exploit the state's natural resources. In these circumstances, recognition by third states of the opposing party as the representative of the state, or even allowing the opposition to exploit the state's natural resources to the detriment of the lawful government, constitutes a violation of the principle of non-intervention. ${ }^{27}$ While effectiveness is therefore an essential aspect with regard to the question of whether a new government represents the state in international law, it is less so for determining which entity is entitled to represent the state in situations of internal armed conflicts.

The doctrine of effective control is furthermore balanced by the second criterion, which requires that a government should possess a valid legal title to represent the state. Even though unconstitutional changes in government do not affect the identity of the state as such, ${ }^{28}$ state practice demonstrates that the international community attaches importance to the existence of a valid legal title for state representation. This is first of all apparent from the reactions of the international community to coups d'états, such as those in Haiti in 1991, in Sierra Leone in 1997 and, more recently, in the Central African Republic in 2013. In all these situations the coup

\footnotetext{
25 Lauterpacht (2013) (first published 1947), p. 94.

26 See Ruys (2014), p. 38.

27 The 1970 Friendly Relations Declaration states in relation to the principle of non-intervention that "no State shall organize, assist, foment, finance, incite or tolerate subversive, terrorist or armed activities directed towards the violent overthrow of the regime of another State, or interfere in civil strife in another State'. See Declaration on Principles of International Law Concerning Friendly Relations and Cooperation among States in Accordance with the Charter of the United Nations, Annex to UN General Assembly Res. 2625 (XXV) of 24 October 1970.

28 This is a long-standing view, which has been confirmed throughout the years. Hersch Lauterpacht stated in 1947 that 'the nature of the change [in government] is of no legal relevance. ... From the point of view of ... international law there is no difference between a constitutional and a revolutionary change of government'. See Lauterpacht (2013) (first published 1947), p. 92. Likewise, Hans Kelsen stated in 1967 that ' $[\mathrm{t}]$ he government brought into permanent power by a revolution or a coup d'état is, according to international law, the legitimate government of the state whose identity is not affected by these events'. See Kelsen (1967), p. 387. It is essential to note that these authors did not inquire into the legality of the government itself, but examined the legal effects of an unconstitutional change of government on the continuity of the state.
} 
was condemned by the international community, including by the UN Security Council. $^{29}$

In addition, the importance attached by the international community to a valid legal title is reflected in several regional conventions which attach legal consequences to unconstitutional changes in government. Article 7(g) of the 2002 Protocol Relating to the Establishment of the Peace and Security Council of the African Union provides, for example, that the African Peace and Security Council shall 'institute sanctions whenever an unconstitutional change of Government takes place in a Member State, as provided for in the Lomé Declaration'. ${ }^{30}$ Acting upon the Protocol, the African Peace and Security Council suspended the Central African Republic immediately after the 2013 coup d'état. ${ }^{31}$ Similarly, Article 9 of the Charter of the Organization of American States provides that the right to participate in the sessions of the principal organs of the organization may be suspended for a member of the Organization whose democratically constituted government has been overthrown by force. ${ }^{32}$ This provision was invoked to suspend Honduras following the coup d'état in $2009 .^{33}$

This practice demonstrates that effectiveness is not the sole decisive factor in determining which entity is entitled to represent the state and, therefore, to exercise control over the state's natural resources. The existence of a valid legal title is of equal importance. The question that subsequently arises is whether there are any circumstances in which governments in power are no longer considered to constitute the de jure government, implying that they are no longer entitled to exploit the state's natural resources.

A distinction should be made in this regard between the establishment of a new government and the continued recognition of the established government. For new governments the existence of a valid legal title is important. The practice discussed

\footnotetext{
29 See UN Security Council Res. 841 (1993) in relation to Haiti, in which the SC deplored the fact that 'despite the efforts of the international community, the legitimate government of Jean Bertrand Aristide has not been reinstated', 1132 (1997) on Sierra Leone, in which the SC demanded that the military junta 'take immediate steps to relinquish power in Sierra Leone and make way for the restoration of the democratically elected Government and a return to constitutional order', and 2121 (2013) for the Central African Republic in which the SC reiterated its condemnation previously expressed through a Press Statement dated 25 March 2013 'of the seizure of power by force on 24 March 2013 by the Seleka coalition'.

30 See Protocol Relating to the Establishment of the Peace and Security Council of the African Union, Adopted by the 1st Ordinary Session of the Assembly of the African Union, on 9 July 2002. The Lomé Declaration distinguishes the following situations as unconstitutional changes in government: (1) military coup d'état against a democratically elected government; (2) intervention by mercenaries to replace a democratically elected government; (3) replacement of democratically elected governments by armed dissident groups and rebel movements; (4) the refusal by an incumbent government to relinquish power to the winning party after free, fair and regular elections. See the Lomé Declaration of July 2000 on the framework for an OAU response to unconstitutional changes of government (AHG/Decl.5 (XXXVI).

31 Peace and Security Council, Communiqué of 25 March 2013, Doc. PSC/PR/COMM.(CCCLXIII), especially para. 8 .

32 Charter of the Organization of American States, adopted on 30 April 1948 (last amended on 10 June 1993), 119 UNTS 3.

33 See the following decisions by the OAS General Assembly: AG/RES. 1 (XXXVII-E/09) (July 1, 2009), 37th Sess., OEA/Ser.P/XXXVII-E/09 (2009) and AG/RES. 2 (XXXVII-E/09) (July 4, 2009), 37th Sess., OEA/Ser.P/XXXVII-E/09 (2009). See also Cassel (2009).
} 
in this section relates exclusively to unconstitutional changes in government. For the established authorities, the existence of a valid legal title is generally presumed. This also explains why a de jure government which has lost effective control over portions of the state territory following an internal armed conflict is still considered to represent the state in international law. Whether the actions of a government may deprive it of its status as a lawful government is discussed in Sect. 4.2 with reference to the situations in Libya and Syria, while Sect. 4.3 discusses the legal status of the opposition movements in Libya and Syria.

\subsection{Attitude of the International Community towards the Libyan and Syrian Authorities}

Both in the Libyan and the Syrian armed conflict, the authorities ordered systematic attacks against the civilian population, amounting to the commission of international crimes. The Independent International Commission of Inquiry on the Syrian Arab Republic that was established by the Human Rights Council to investigate alleged violations of international human rights law since March 2011 in Syria formulated the following conclusions in its August 2014 report:

Government forces continued to perpetrate massacres and conduct widespread attacks on civilians, systematically committing murder, torture, rape and enforced disappearance amounting to crimes against humanity. Government forces have committed gross violations of human rights and the war crimes of murder, hostage-taking, torture, rape and sexual violence, recruiting and using children in hostilities and targeting civilians. Government forces disregarded the special protection accorded to hospitals and medical and humanitarian personnel. Indiscriminate and disproportionate aerial bombardment and shelling led to mass civilian casualties and spread terror. Government forces used chlorine gas, an illegal weapon. ${ }^{34}$

For Libya, the systematic attacks by the authorities against the civilian population constituted the primary reason for the Security Council to adopt measures under Chapter VII of the UN Charter, including a referral of the situation to the ICC and an authorization for member states 'to take all necessary measures ... to protect civilians and civilian populated areas under threat of attack in [Libya]' ${ }^{35}$ It based these decisions on the failure of the Libyan authorities to respect its responsibility to protect its population. $^{36}$

Notwithstanding the condemnation expressed by the international community in connection to the atrocities committed by the Libyan and Syrian authorities, it is striking that neither the Security Council nor-in the absence of agreement between the Security Council members in relation to Syria-the General Assembly in their

\footnotetext{
${ }^{34}$ Report of the Independent International Commission of Inquiry on the Syrian Arab Republic, UN Doc. A/HRC/27/6016, Summary, published on 27 August 2014.

35 See UN Security Council Res. 1970 (2011), para. 4 and UN Security Council Res. 1973 (2011), para. 4.

36 Ibid., the Security Council refers in both resolutions to the responsibility of the Libyan authorities to protect its population.
} 
resolutions have suggested that the respective authorities would no longer qualify as the government. Even though the Security Council imposed asset freezes on the Libyan authorities, including in connection to the state's oil reserves, it refrained from making any statements regarding the legal status of the Libyan government. The sanctions aimed to coerce the government to stop the killing; they did not have a direct impact on the legal position of the government as such.

In view of the stalemate in the Security Council in relation to Syria, reference can be made to relevant resolutions adopted by the General Assembly as expressions of the collective position of the international community in relation to Syria. These resolutions contain firm language with respect to the Syrian authorities, yet they do not denounce the government as such. The most far-reaching passages of these resolutions relate to the political transition process envisaged for Syria, based on the 2012 Geneva communiqué of the Action Group for Syria. ${ }^{37}$ These passages contain proposals for the establishment of a transitional government, consisting of representatives of the Syrian opposition as well as the Assad government. While the passages therefore aim at dissolving the Assad government, they do not directly impact upon the current status of the Assad government. In addition, it should be noted that the approach of the General Assembly does not differ in this respect from the one taken by the Security Council, which is actively involved in the peace process. In its resolution of 17 December 2014 in relation to Syria, the Security Council 'reiterates that the only sustainable solution to the current crisis in Syria is through an inclusive and Syrian-led political process that meets the legitimate aspirations of the Syrian people, with a view to full implementation of the Geneva Communiqué'. 38

The most important conclusion that can be drawn from these reactions is that the atrocities committed by the governments in Libya and Syria have faced widespread condemnation, yet they have not resulted in formal statements denouncing the position of the established authorities as the representative of the state. A distinction should therefore be made between condemnation voiced by the international community with respect to the acts of the government, on the one hand, and a decision to withdraw the recognition of the established authorities as the lawful government, on the other.

Where UN organs have not gone as far as to denounce the Libyan and Syrian authorities, it is interesting to take a closer look at the attitudes of individual states towards the Libyan and Syrian authorities. Most telling in this respect is the reaction of the US in connection to the Assad regime. The US has pushed for the removal of the Assad regime from the moment that it became clear that the regime used chemical weapons against its own population. It has also suspended most of its diplomatic relations with the Assad government and openly provides support to the moderate opposition forces. ${ }^{39}$ Nevertheless, the US has also consistently been

\footnotetext{
37 See UN General Assembly Res. 67/262 (2013) on the situation in the Syrian Arab Republic, para. 28. The Action Group for Syria consists inter alia of the UN Secretary-General, individual states (including the permanent members of the Security Council) and several regional organisations, including the Arab League and the European Union.

38 See UN Security Council Res. 2191 (2014), para. 4.

39 See e.g. Blanchard et al. (2014).
} 
involved in peace talks with the Assad government and the opposition. Even though it is abundantly clear that the US no longer supports the Assad government or is willing to conduct bilateral diplomatic relations with it, the US has not officially withdrawn its recognition of the government as such.

The question arises whether a withdrawal of recognition can nevertheless be inferred from the attitude of the international community towards the opposition movements in Libya and Syria. Recognition of the opposition as the government would automatically entail the de-recognition of the established authorities. This issue is examined in the following section.

\subsection{Attitude of the International Community towards the Libyan and Syrian Opposition}

In both the Libyan and Syrian armed conflict, the opposition organized itself in the course of the armed conflict by establishing a political body to act as its representative in its relations with the international community. In Libya, the NTC was established in March 2011. In its founding statement, it declared itself to be 'the sole representative of all Libya'. ${ }^{40}$ Likewise, in the Syrian armed conflict the moderate opposition forces formed a National Coalition for Syrian Revolutionary and Opposition Forces (NCS), commonly known as the Syrian National Council in November $2012 .^{41}$

Individual states and international organizations started to express their recognition for the NTC and the NSC soon after the establishment of these bodies. It should however be noted that states did not recognise these bodies as the official government of Libya or Syria, but rather as the-or even $a$-representative of the Libyan or Syrian people, which amounts to political and not legal recognition. ${ }^{42}$ Likewise, the General Assembly in its Resolution 67/262 (2013) welcomed the establishment of the NCS 'as effective representative interlocutors needed for a political transition', while noting 'the wide international acknowledgement ... of the Coalition as the legitimate representative of the Syrian people'.

According to Talmon, political recognition of an opposition group 'means that the recognizing state is willing to enter into political and other relations with that group'. ${ }^{43}$ This type of recognition therefore paves the way to establishing diplomatic relations with the opposition movement. However, it does not imply that the opposition movement is considered to be entitled to assume international rights and obligations on behalf of the state, including rights over natural resources situated within the state's territory.

\footnotetext{
${ }^{40}$ Founding Statement of the Interim Transnational National Council (TNC), 5 March 2011. http://www. lcil.cam.ac.uk. Accessed December 2014.

41 See http://en.etilaf.org. Accessed December 2014. It should be noted that the NCS only comprises moderate opposition forces. Extremist organizations such as ISIL and Al-Nusra are not part of it.

42 See Talmon (2011) and Talmon (2013), pp. 219-253. These articles also provide an overview of the exact phrasing of all acts of recognition of the Libyan and Syrian opposition.

43 See Talmon (2013), p. 231.
} 
In other words, since the recognition accorded to these bodies by states and international organizations was merely political it did not affect the legal position of the Gaddafi or Assad regime as the official de jure government of Libya or Syria respectively. In relation to Libya, the official position of states changed only after the defeat of the Gaddafi regime. This is exemplified by UN Security Council Resolution 2009 (2011), in which the Council implicitly recognised the NTC as the new Libyan authorities after the armed conflict had ended. This also implies that the Gaddafi and Assad regimes remain(ed) formally entitled to dispose of the state's natural resources to the exclusion of other actors, even though this right could not in practice be exercised by the Gaddafi government as a result of the sanctions imposed by the Security Council on the National Oil Company.

The cautious practice of states with regard to the recognition of the Libyan and Syrian opposition underlines the continued validity of the rule identified in Sect. 4.1 regarding the prohibition on extending recognition to revolutionary forces as long as the conflict has not ended. This also implies that armed opposition groups would be prohibited from exploiting natural resources situated within national jurisdiction. Nonetheless, as briefly noted in Sect. 3, 'peoples' are designated as subjects of the principle of PSNR in addition to states. The following section analyses the implications of this designation for the purposes of natural resources exploitation with the aim of establishing whether affording recognition to the opposition as the representative of the people entails a right for the opposition to exploit the state's natural resources on behalf of the people.

\section{Peoples as Subjects and Beneficiaries of the Right to Sovereignty over Public Natural Resources}

The 1962 Declaration on Permanent Sovereignty over Natural Resources and the 1966 human rights covenants accord a central position to peoples as beneficiaries and holders of the right to sovereignty over natural resources. ${ }^{44}$ The very first principle of the authoritative 1962 Declaration on Permanent Sovereignty over Natural Resources, adopted by the UN General Assembly, proclaims a right for peoples and nations to permanent sovereignty over their natural wealth and resources, while conditioning the exercise of this right on the premise that this must be done 'in the interest of their national development and of the well-being of the people of the State concerned'. 45

The central position of peoples with respect to natural resources ownership has further been confirmed in the identical Articles 1(2) of the International Covenant on Economic, Social and Cultural Rights (ICESCR) and the International Covenant on Civil and Political Rights (ICCPR), which incorporate the economic component of the right to self-determination. These provisions determine that '[a]ll peoples

\footnotetext{
44 See Dam-de Jong (2015), pp. 58-104 for a more elaborate discussion on the position of peoples with respect to natural resources.

45 Declaration on Permanent Sovereignty over Natural Resources, UN General Assembly Res. 1803 (XVII) of 14 December 1962.
} 
may, for their own ends, freely dispose of their natural wealth and resources', while they emphasize that 'in no case may a people be deprived of its own means of subsistence'. ${ }^{46}$ This right is inextricably linked to the political component of the right to self-determination, incorporated in Articles 1(1) of the ICESCR and the ICCPR, which provides peoples with the right to choose their political system and to pursue their economic, social and cultural development.

Both legal documents therefore affirm that peoples-in addition to states-are subjects of the right to exercise control over public natural resources, while the 1962 Declaration also emphasises that peoples are beneficiaries of this right. A peopleoriented conception of natural resources ownership has received recognition in several contemporary legal and political instruments addressing the contribution of natural resources in financing armed conflicts, most particularly in resolutions adopted by the UN Security Council, in peace agreements and in regional treaties. Examples include UN Security Council Resolution 1457 (2003) on the DR Congo, in which the Security Council reaffirms the sovereignty of the DRC over its natural resources and emphasises that these should be exploited 'to benefit the country and its people'. ${ }^{47}$ Also, in its Resolution 1521 (2003) on Liberia, the Council emphasises that government revenues from the timber industry must be used 'for legitimate purposes for the benefit of the Liberian people'. ${ }^{48}$

Examples from peace agreements include Article VII of the Lomé Peace Agreement of 7 July 1999, concluded between the government of Sierra Leone and the Revolutionary United Front, which provides that the government shall exercise control over the state's natural resources 'for the benefit of the people of Sierra Leone'. Finally, Article 3 of the Protocol of the Great Lakes Region Against the Illegal Exploitation of Natural Resources of 30 November 2006, a regional treaty adopted by the states situated in the African Great Lakes region, determines that the right of the respective states to freely dispose of their natural resources 'shall be exercised in the exclusive interest of the people'.

These contemporary instruments therefore clearly establish that peoples are to be regarded as beneficiaries of the right for states to exercise control over natural resources. The 1962 Declaration on PSNR and the identical Articles 1(2) of the ICESCR and the ICCPR however also designate peoples as subjects of the right to dispose freely of natural resources. The question that arises is what this right entails and to whom it accrues. Since the relevant legal instruments were drafted in the era of decolonization, it should be established, first of all, whether the term 'peoples' has any independent meaning outside this context, i.e. whether it applies to peoples living in independent states generally. ${ }^{49}$

\footnotetext{
461966 International Covenant on Economic, Social and Cultural Rights (ICESCR), New York, Annex to UN General Assembly Res. 2200 (XXI) of 16 December 1966 (entry into force: 3 January 1976), 993 UNTS 3; 1966 International Covenant on Civil and Political Rights (ICCPR), New York, Annex 2 to UN General Assembly Res. 2200 (XXI) of 16 December 1966 (entry into force: 23 March 1976), 999 UNTS 171.

47 UN Security Council Res. 1457 (2003), para. 4.

48 UN Security Council Res. 1521 (2003), para. 11.

49 See e.g. Crawford (1988).
} 
As a starting point it is argued that the right to self-determination does not cease to exist once a state has been established. ${ }^{50}$ While it may be assumed that the externalor inter-state-dimension of the right to self-determination dissolves into state sovereignty once a state has been established, the internal-or intra-statedimension of the right to self-determination continues to exist. Based on this primary assumption, the more relevant question is to establish what the right entails for the purposes of natural resources exploitation and to whom it applies specifically. As to the addressees, it is argued that three distinct groups are entitled to exercise a right to internal self-determination, and therefore, are to be considered subjects of the principle of sovereignty over natural resources in addition to states. These are the population of a state as a whole, minorities and indigenous peoples. In view of the focus of this article on the question of who may represent the people in situations of internal power contests, this section is limited to an analysis of the position of the first group, i.e. the population as a whole as the sum of all peoples living in a state. ${ }^{51}$

The population as a whole is entitled to exercise a right to internal selfdetermination on the basis of Articles 1 of the ICESCR and the ICCPR. ${ }^{52}$ Pursuant to Articles 1(1) of the ICESCR and the ICCPR, this right entails, first of all, a right to freely choose the state's political and economic system. ${ }^{53}$ As Rosalyn Higgins noted: 'self-determination requires the ongoing choice of the people as to their governance, and, in turn, their economic, social and cultural development'. ${ }^{54}$ One of the principal ways of achieving the right to internal self-determination for the

\footnotetext{
50 The question of whether a right to self-determination accrues to peoples living within independent states was a matter of considerable controversy at the San Francisco Conference establishing the United Nations, notably because of the fear of several states that it would be interpreted as a right to secession. On the San Francisco debates, see Spijkers (2011), Ch. VII. The applicability of self-determination to peoples living within states has been affirmed by the 1970 Declaration on Principles of International Law Concerning Friendly Relations and Co-Operation Among States in Accordance with the Charter of the United Nations (1970 Friendly Relations Declaration), UN General Assembly Res. 2625 (XXV) of 24 October 1970, which indicates that the UN Charter principle of equal rights and self-determination requires a representative government. See further Rosenstock (1971), especially p. 732. Since then, the applicability of self-determination within autonomous states has been reaffirmed on many occasions, including in the case law of the International Court of Justice.

51 For a more detailed analysis of the rights of indigenous peoples in relation to natural resources situated on their lands, see Dam-de Jong (2015), Ch. 3 and Schrijver (2008). See also the final report of the Special Rapporteur of the Commission on Human Rights, Mrs. Erica Daes, on Indigenous peoples' permanent sovereignty over natural resources, UN Doc. E/CN.4/Sub.2/2004/30 of 13 July 2004 and its addendum, UN Doc. E/CN.4/Sub.2/2004/30/Add.1 of 12 July 2004. For a more detailed analysis of the special position of indigenous peoples in international law more generally, see Xanthaki (2007). It is relevant to note that the resource-related rights of indigenous peoples are mostly based on the right of minorities to enjoy their culture on the basis of Art. 27 of the ICCPR.

52 For a different view, see Talmon (2013), pp. 235-237. Talmon argues that in the case of a single people [i.e. the population as a whole], the right of self-determination becomes the right of the State and is directed against "external interference" by other States'. Arguably, this is only so for the right to external self-determination and concerns the question of state representation-which is the primary topic of Talmon's article.

53 Or, as Cassese argues: '[i]nternal self-determination means the right to authentic self-government, that is, the right for a people really and freely to choose its own political and economic regime', Cassese (1995), p. 101.

54 Higgins (1994), p. 120.
} 
population as a whole is to establish proper procedures for decision-making, which allow for the participation of all the parties concerned.

This interpretation of the identical Articles 1 of the ICESCR and the ICCPR has also been articulated by the Human Rights Committee, which noted that the relevant obligations in Article 1 of the ICCPR include first of all the establishment of constitutional and political processes 'which in practice allow the exercise of th[e] right [to self-determination]'. 55 The Human Rights Committee's emphasis on 'practice' is of the essence, since it requires states to put in place policies which effectively guarantee the exercise of the right to self-determination by (individual members of) their population. This also includes an obligation for the state to establish constitutional and political processes allowing people to exercise their right to freely dispose of their natural resources pursuant to Art. 1(2) of the ICCPR. Arguably, this entails a right for the population to be involved in decisions regarding the allocation of natural resources.

The right to internal self-determination of the population as a whole therefore takes shape in the form of procedural or 'public participation' rights within the established structures of the state. As a minimum guarantee, the identical Articles 1(2) of the 1966 covenants furthermore determine that 'in no case may a people be deprived of its means of subsistence'. This prohibition establishes the ultimate limits for governments with respect to the use of the state's natural resources in the sense that the exercise of permanent sovereignty by the government may never result in peoples being deprived of their means of subsistence. ${ }^{56}$ Arguably, this is the case when a government uses the revenues derived from natural resources exploitation to fund a destructive military campaign against its own population, as happened in Libya in 2011 and is still happening in Syria.

This is also the context in which UN Security Council Resolutions 1970 and 1973 on Libya referred to in the introduction of this article should be read. These resolutions determined that assets owned or controlled by the Libyan authorities or persons and entities affiliated to them, including those of the Libyan National Oil company, were to be frozen and 'shall, at a later stage, as soon as possible be made available to and for the benefit of the people of the Libyan Arab Jamahiriya'. ${ }^{57}$ While these resolutions recognise that natural resources belong to the people, they also make clear that the right to dispose of natural resources can only be exercised by a lawful government.

Affording recognition to the opposition as the representative of the people therefore does not entail a right for the opposition to exploit the state's natural resources on behalf of the people. The right to internal self-determination of

\footnotetext{
55 See General Comment No. 12: The right to self-determination of peoples (Art. 1), adopted by the Human Rights Committee at its twenty-first session, 13 March 1984, Office of the High Commissioner for Human Rights, para. 3 and Guidelines for the treaty-specific document to be submitted by states parties under Art. 40 of the International Covenant on Civil and Political Rights, UN Doc. CCPR/C/2009/1 of 22 November 2010, under Art. 1.

56 The formulation of the prohibition in absolute terms implies that it remains applicable in situations of armed conflict. This presumption is strengthened by the fact that international humanitarian law, as the lex specialis in situations of armed conflict, does not contain rules that conflict with this provision.

57 See UN Security Council Res. 1973 (2011), paras. 19 and 20 read in conjunction with Res. 1970 (2011), para. 17.
} 
peoples_-in the sense of the whole population of a state-primarily finds expression in public participation rights within the existing state structures. Bestowing a right to exploit natural resources on an entity other than the government on the basis of the recognition of this entity as the representative of the people would stretch too far. Even though peoples can be regarded as owners of public natural resources, it is the government that should exercise this right on their behalf. The right to internal self-determination of peoples therefore does not provide a legal basis for a right of the opposition to exploit public natural resources. The following section discusses an alternative mode for granting such a right to armed opposition groups on the basis of international humanitarian law.

\section{Reconciling Practice with the Law by Applying the Right to Usufruct to Armed Opposition Groups}

The previous sections showed that current international law does not provide a legal basis for granting armed opposition groups a right to exploit natural resources found within national jurisdiction. This section argues that a case can nevertheless be made in favour of granting armed opposition groups such a right, provided that certain conditions are fulfilled. ${ }^{58}$ One of the most compelling arguments in favour of granting armed opposition movements such a right is related to the nature of internal armed conflicts. In these armed conflicts, the government does not solely represent the state; it is also a party to the armed conflict. In addition, every conflict dynamics is different: just like governments do not necessarily represent a good cause, armed opposition groups do not necessarily struggle for a bad cause. This is especially true for the armed conflicts studied in the current article. In light of these specific circumstances, can one expect an armed group to comply with rules of international humanitarian law formulating a complete prohibition on exploiting natural resources, while the opposing party has a broadly defined right to exploit natural resources pursuant to the principle of PSNR?

This article therefore proposes to grant those armed opposition groups that are in effective control of a portion of the state territory a qualified right to exploit natural resources, based on the right of usufruct that is central to international occupation law. ${ }^{59}$ Where the general rules of international humanitarian law do not contain specific provisions regulating the exploitation of natural resources, the international law on occupation does. This is due to the specific nature of international occupation law, which is designed to regulate the actions of the occupier as the de facto authority exercising power over a territory. ${ }^{60}$ Section 6.1 discusses the nature of the right of usufruct, while Sect. 6.2 focuses on the conditions for its application to internal armed conflicts.

\footnotetext{
58 See also Dam-de Jong (2015), pp. 258-259 and 422-424.

59 See also Dam-de Jong (2015), pp. 226-233.

60 See Art. 43 of the 1907 Hague Regulations annexed to Convention (IV) respecting the Laws and Customs of War on Land (The Hague, 18 October 1907) which provides the legal basis for the exercise of de facto authority by the occupant over occupied territory by asserting that 'the authority of the legitimate power [has] in fact passed into the hands of the occupant'.
} 


\subsection{The Nature of the Right of Usufruct}

Under the law of occupation, occupants are granted a qualified right to exploit natural resources pursuant to the concept of usufruct. According to Article 55 of the 1907 Hague Regulations:

The occupying State shall be regarded only as administrator and usufructuary of public buildings, real estate, forests, and agricultural estates belonging to the hostile State, and situated in the occupied country. It must safeguard the capital of these properties, and administer them in accordance with the rules of usufruct.

Even though the provision does not explicitly mention natural resources as such, the references to forests and agricultural estates included in the provision attest to its relevance for natural resources exploitation. It can therefore be argued that occupants are granted a right to exploit natural resources, as long as they 'safeguard the capital of these properties'. There has been considerable scholarly discussion regarding the precise meaning of this phrase in relation to the exploitation of nonrenewable natural resources, such as oil or minerals, since the exploitation of these natural resources by its very essence diminishes their capital. ${ }^{61}$

The principal question is therefore whether the provision prohibits only excessive exploitation of these natural resources or whether it prohibits their exploitation altogether. In the absence of any consensus on this issue, the position of this article is that the exploitation of non-renewable natural resources by an occupant is allowed within the limits set by modern international law in relation to sustainable development. This implies that an occupant is allowed to exploit the natural resources in occupied territory in so far as this would not harm the options of future generations to exploit the natural resources for their development. ${ }^{62}$

Furthermore, pursuant to the principle of permanent sovereignty over natural resources an occupant must exploit the natural resources in occupied territory for the benefit of the occupied territory and its population. ${ }^{63}$ It is also in this sense that the post-WWII tribunals interpreted the right to usufruct of an occupant, obviously without referring to the principle of PSNR which has been promulgated after the trials had ended. The International Military Tribunal at Nuremberg considered that 'the economy of an occupied country can only be required to bear the expense(s) of the occupation, and these should not be greater than the economy of the country can

\footnotetext{
61 See e.g. B. Sloan, 'Study on the Implications, under International Law, of the United Nations Resolutions on Permanent Sovereignty over Natural Resources, on the Occupied Palestinian and other Arab Territories and on the Obligations of Israel Concerning its Conduct in these Territories', UN Doc. A/38/85, 21 June 1983; Cassese (1992), Schrijver (1997), pp. 268-269, Langenkamp and Zedalis (2003), pp. 417-435 and Benvenisti (2013), pp. 81-82.

${ }^{62}$ For an overview of the principles relating to sustainable development, see the ILA New Delhi Declaration of Principles of International Law Relating to Sustainable Development (2002) and the Final Report of the ILA Committee on Legal Aspects of Sustainable Development, 'Searching for the Contours of International Law in the Field of Sustainable Development' (2002). http://www.ila-hq.org/en/ committees.

63 For the impact of the principle of permanent sovereignty on the interpretation of the right of usufruct, see Arai-Takahashi (2009), pp. 215-216.
} 
reasonably be expected to bear' ${ }^{64}$ This judgment should be read in conjunction with the Krupp case, decided by a lower military tribunal at Nuremberg. This tribunal considered that an occupied country's economic assets could never be used for military operations against the occupied territory. ${ }^{65}$ A modern interpretation of these judgments suggests that an occupant is permitted to use the proceeds from exploiting resources for the purposes of maintaining a civilian administration in occupied territory, but not to cover the costs associated with military operations.

The qualified nature of the concept of usufruct therefore strikes a careful balance between the realities of armed conflict and the provisional character of the situation. If applied to internal armed conflicts, it would allow armed opposition groups to exploit the natural resources in the territory under their control, while they may only use the proceeds for the purpose of establishing and maintaining a civilian administration.

\subsection{Conditions for the Application of the Right to Usufruct to Internal Armed Conflicts}

The concept of usufruct applies to situations of occupation. Article 42 of the 1907 Hague Regulations determines that 'territory is considered occupied when it is actually placed under the authority of the hostile army'. It further determines that 'the occupation extends only to the territory where such authority has been established and can be exercised'. If the concept of usufruct were to be applied by analogy to internal armed conflicts, it would therefore only apply to territories which are under the effective control of an armed group. In addition, this group would have to be highly organised in order to be able to exercise its authority over the territory under its control. This implies that the armed group must be able to implement the basic obligations that are imposed on occupants pursuant to Article 43 of the 1907 Hague Regulations, which states that the occupant 'shall take all the measures in his power to restore, and ensure, as far as possible, public order and safety, while respecting, unless absolutely prevented, the laws in force in the country'. In other words, the armed group must be able to act within the territory under its control as a de facto authority.

It is further essential to emphasise that affording a right to armed groups to exploit natural resources on the basis of the concept of usufruct does not give these groups a carte blanche to use these natural resources as they see fit. As emphasised in Sect. 6.1, the right to usufruct is qualified in the sense that it only allows armed groups to exploit natural resources for the purpose of maintaining a civilian administration. The rationale for granting armed groups this right is to enable them to assume governmental functions in the territory under their control. However,

\footnotetext{
64 Trial of the Major War Criminals before the International Military Tribunal, Nuremberg, 14 November 1945-1 October 1946, Official Documents, Vol. I, Nuremberg (1947), p. 239.

65 Trials of War Criminals before the Nuremberg Tribunals under Control Council Law No. 10, Vol. IX, the Krupp case, Washington: Government Printing Office (1950), p. 1341. The tribunal held in relevant part: 'Just as the inhabitants of the occupied territory must not be forced to help the enemy in waging the war against their own country or their own country's allies, so must the economic assets of the occupied territory not be used in such a manner'.
} 
when it is clear that an armed group engages in gross human rights violations in the territories under its control, there are ways to revoke the right to exploit natural resources for this group. More specifically, it should be emphasised that granting a right to usufruct to armed opposition groups does not prevent the UN Security Council or regional organisations from the possibility to impose sanctions in particular situations.

The UN Security Council has resorted to the imposition of sanctions on armed groups on many occasions. These range from commodity sanctions in relation to Angola, Sierra Leone, Côte d'Ivoire and Somalia to asset freezes against persons and entities providing support to armed groups in the DR Congo. ${ }^{66}$ Of special interest to this article are two resolutions passed by the Security Council in relation to Syria. In its Resolution 2170 (2014), the Security Council noted with concern that oil was generating income for extremist organisations operating in Syria, including ISIL and Al-Nusra, and made it clear that trade with these armed groups could constitute financial support for entities on a sanctions list. ${ }^{67}$ Resolution 2199 (2015) builds on this and previous resolutions. It contains a complete section on oil trade, in which the Council specifically:

Condemns any engagement in direct or indirect trade, in particular of oil and oil products, and modular refineries and related material, with ISIL, ANF and any other individuals, groups, undertakings and entities designated as associated with Al-Qaida by the Committee pursuant to resolutions 1267 (1999) and 1989 (2011), and reiterates that such engagement would constitute support for such individuals, groups, undertakings and entities and may lead to further listings by the Committee. ${ }^{68}$

There are therefore appropriate mechanisms to prevent armed groups that pose a particular threat to peace and security from reaping the benefits of natural resources exploitation in the territories under their control.

\section{Conclusions}

This article set out to answer the question of whether a legal basis could be found in international law for granting armed opposition groups a right to exploit natural resources, particularly in light of the 2011 armed conflict in Libya, the current armed conflict in Syria and the EU decision to provide an exemption to the oil sanctions imposed against Syria in favour of oil exports from rebel-held territory. It

\footnotetext{
66 See e.g. UN Security Council Res. 1173 (1998) and 1176 (1998) imposing diamond sanctions against UNITA in Angola; Res. 1306 (2000) imposing diamond sanctions against the RUF in Sierra Leone; Res. 1643 (2005) imposing diamond sanctions against the Forces Nouvelles in Côte d'Ivoire; Res. 2036 (2012) imposing sanctions on charcoal against Al Shabaab in Somalia; and Res. 1857 (2008) extending the existing financial and travel sanctions in relation to the DR Congo to individuals or entities supporting the illegal armed groups [operating] in the eastern part of the Democratic Republic of the Congo through the illicit trade of natural resources'.

67 See UN Security Council Res. 2170 (2014), paras. 13-14.

68 UN Security Council Res. 2199 (2015), para. 1.
} 
found that a legal basis for granting a right to armed opposition groups to exploit natural resources is currently lacking.

First, such a right cannot be based on international humanitarian law as it currently stands. The rules applicable to non-international armed conflicts do not contain a right for armed groups to exploit natural resources. Second, such a right cannot be based on general international law either. International law designates ownership of natural resources to states and peoples, without specifying which entity is to exercise the associated rights and obligations on their behalf. In the majority of situations, a state possesses a government which represents the state on the international plane. The situation becomes more problematic in situations of internal armed conflict, where parties fight over control over territory.

This article demonstrated that the loss of effective control over parts of the territory by the established authorities does not impact upon their legal status. International law formulates a presumption that the established authorities continue to represent the state in international law during the course of the armed conflict. Recognition of the opposition as the government would be premature in these circumstances and would therefore qualify as a breach of the principle of nonintervention. This explains why states have been hesitant to accord this legal status to the armed opposition in Libya and Syria and have instead only granted political recognition to the opposition. This in itself does not grant the opposition a right to exploit the state's natural resources. Even though peoples are subjects of the principle of permanent sovereignty over natural resources, a qualification of the opposition as the representative of the people does not entail a right to exploit natural resources.

Nevertheless, there are good reasons to grant armed opposition groups a right to exploit natural resources, provided these groups are highly organised and in effective control of territory. Moreover, they must be capable of establishing and maintaining authority over this territory. Granting armed opposition groups a qualified right to exploit natural resources in territory under their control would provide these groups with the opportunity to establish a civilian administration for the benefit of the population, while it leaves intact the possibility to take enforcement measures in individual cases. Ultimately, it is argued that applying the carefully delineated right of usufruct to territories under the effective control of armed groups would contribute to-rather than undermine - the realisation of the principal objectives of international humanitarian law, in particular to protect the civilian population from the atrocities of armed conflict.

Open Access This article is distributed under the terms of the Creative Commons Attribution License which permits any use, distribution, and reproduction in any medium, provided the original author(s) and the source are credited.

\section{References}

Arai-Takahashi Y (2009) The law of occupation: continuity and change of international humanitarian law, and its interaction with human rights law. Martinus Nijhoff Publishers, The Hague

Ballentine K, Sherman J (eds) (2003) The political economy of armed conflict. Lynne Rienner Publishers, Boulder/London 
Benvenisti E (2013) The international law of occupation, 2nd edn. Oxford University Press, Oxford Blanchard CM et al (2014) Armed conflict in Syria: overview and US response. Congressional Research Service

Cassel D (2009) Honduras: coup d'état in constitutional clothing. ASIL Insights 13(9). http://www.asil. org/insights/volume/13/issue/9/honduras-coup-d\%E2\%80\%99etat-constitutional-clothing. Accessed 2 March 2015

Cassese A (1992) Powers and duties of an occupant in relation to land and natural resources. In: Playfair E (ed) International law and the administration of occupied territories: two decades of Israeli occupation of the West Bank and Gaza Strip, proceedings of a conference organized by al-Haq in Jerusalem in January 1988. Clarendon Press, Oxford, pp 419-442

Cassese A (1995) Self-determination of peoples: a legal appraisal. Cambridge University Press, Cambridge

Crawford J (1988) The rights of peoples: 'peoples' or 'governments'? In: Crawford J (ed) The rights of peoples. Clarendon Press, Oxford, pp 55-67

Crawford J (2007) The creation of states in international law, 2nd edn. Oxford University Press, Oxford

Dam-de Jong DA (2013) From engines for conflict into engines for sustainable development: the potential of international law to address predatory exploitation of natural resources in situations of internal armed conflict. Nordic J Int Law 82:155-177

Dam-de Jong DA (2015) International law and governance of natural resources in conflict and postconflict situations. Cambridge University Press, Cambridge

Elian G (1979) The principle of sovereignty over natural resources. Sijthoff \& Noordhoff, Alphen aan den Rijn

Higgins R (1994) Problems and process: international law and how we use it. Clarendon Press, Oxford

Kelsen H (1967) Principles of international law, 2nd edn. Holt, Rinehart and Winston, New York

Langenkamp RD, Zedalis RJ (2003) What happens to the Iraqi oil? Thoughts on some significant, unexamined international legal questions regarding occupation of Iraqi oil fields. Eur J Int Law $14: 417-435$

Lauterpacht H (first published in 1947; 2013 paperback edition) Recognition in international law. Cambridge University Press, Cambridge

Rosenberg D (1983) Le principe de souveraineté des états sur leurs ressources naturelles. Librairie Générale de Droit et de Jurisprudence, Paris

Rosenstock R (1971) The declaration of principles of international law concerning friendly relations: a survey. Am J Int Law 65:713-735

Ruys T (2014) Of arms, funding and 'non-lethal assistance'-issues surrounding third-state intervention in the Syrian civil war. Chin J Int Law 13:13-53

Schrijver NJ (1997) Sovereignty over natural resources: balancing rights and duties. Cambridge University Press, Cambridge

Schrijver NJ (2008) Unravelling state sovereignty? The controversy on the right of indigenous peoples to permanent sovereignty over their natural wealth and resources. In: Boerefijn I, Goldschmidt J (eds) Changing perceptions of sovereignty and human rights: essays in honour of Cees Flinterman. Intersentia, Antwerp/Oxford/Portland, pp 85-98

Spijkers O (2011) The United Nations, the evolution of global values and international law. Intersentia, Cambridge

Talmon S (1998) Recognition of governments in international law: with particular reference to governments in exile. Clarendon Press, Oxford

Talmon S (2011) Recognition of the Libyan national transitional council. ASIL Insights 15(16). http:// www.asil.org/insights/volume/15/issue/16/recognition-libyan-national-transitional-council. Accessed 2 March 2015

Talmon S (2013) Recognition of opposition groups as the legitimate representative of a people. Chin J Int Law 12:219-253

Van den Herik LJ, Dam-de Jong DA (2011) Revitalizing the antique war crime of pillage: the potential and pitfalls of using international criminal law to address illegal resource exploitation. Crim Law Forum 3:237-273

Xanthaki A (2007) Indigenous rights and United Nations standards: self-determination, culture and land. Cambridge University Press, Cambridge 